\title{
Evaluation of renal function and subclinical hypothyroidism in persons with type 2 diabetes mellitus
}

\author{
P S Roy ${ }^{1}$, KVN Mallikarjuna Rao $^{2 *}$, Saphya Mukhtar ${ }^{3}$, N Lakshmana Kumar $^{4}$
}

Medical Officer, Gangarampur Super Speciality Hospital, Dakshin Dinajpur, West Bengal, INDIA.

${ }^{2}$ Associate Professor, ${ }^{3}$ Assistant Professor, 4 Professor \& HOD, Department of Biochemistry, GSL Medical College, Rajahmundry, AP, INDIA. Email: kotamalli@gmail.com

Abstract Background: Diabetic nephropathy due to diabetes is a major cause of end-stage renal disease. It is defined as raised urinary albumin excretion in absence of other kidney diseases that may increase risk of death, especially from cardiovascular causes. Thyroid dysfunction can have effect on development of diabetic nephropathy that have not been studied in a widespread way in India. Purpose is to compare subclinical hypothyroidism (SCH) with renal function in persons with type 2 diabetes mellitus (T2DM). Methods: In all the selected 215 subjects of type 2 diabetes mellitus, thyroid function screening was done by using ELFA method. These subjects were divided into two groups including T2DM with SCH (Group A) and T2DM without SCH (Group B). In all these subjects kidney function was assessed by estimating serum creatinine by Jaffe's method and confirmation was done by eGFR using ID-MS traceable MDRD equation. Results: Significant difference between serum TSH, serum creatinine and eGFR was observed between the above said groups. Conclusion: Type 2 diabetic subjects with SCH can result in DN when compared to those without $\mathrm{SCH}$ and those with normal thyroid function.

Key Words: Diabetes Mellitus, HbA1c, SCH, serum TSH, serum FT4, serum creatinine, eGFR by MDRD.

*Address for Correspondence:

Dr. KVN. Mallikarjuna Rao, Associate Professor, Department of Biochemistry, GSL Medical College, Rajahmundry, Andhra Pradesh.

Email: kotamalli@gmail.com

Received Date: 16/07/2019 Revised Date: 02/08/2019 Accepted Date: 23/09/2019

DOI: https://doi.org/10.26611/10021211

\begin{tabular}{|l|l|}
\hline \multicolumn{2}{|c|}{ Access this article online } \\
\hline Quick Response Code: & Website: \\
\hline & www.medpulse.in \\
\cline { 2 - 2 } & \\
\hline
\end{tabular}

\section{INTRODUCTION}

Diabetes, an endocrinal disorder is a group of metabolic disorders of carbohydrate metabolism producing hyperglycemia. It is increasing significantly worldwide. ${ }^{1,2,3}$ which leads to an increase in development of microvascular complications like diabetic nephropathy (DN). End-stage renal disease (ESRD) may result because of $\mathrm{DN}$, contributing to evidential increase in morbidity and mortality in persons with diabetes mellitus3. DN resulting from strong influence of thyroid hormones has excited the interests recently. Thyroid hormones have active role in regulation of kidney development, renal hemodynamics, GFR and sodium and water balance. Sub clinical hypothyroidism $(\mathrm{SCH})$ can result in kidney dysfunction through decreased GFR, change in vascular and heart function and disturbance in Renin-Angiotensin system. ${ }^{6,7,8}$

Several studies suggested. ${ }^{9,10}$ That subclinical hypothyroidism is associated with evolution of microalbuminuria and DN. Many recent studies reported that low to normal thyroid hormones are linked with risk factors of DN like endothelial function, plasma lipid levels 7 hypertension. Other longitudinal studies ${ }^{13,14}$ showed correlation between low-to-normal thyroid hormones and frequency of occurrence of macrovascular diseases. DN results in progressive loss of kidney function. Hence, it is necessary to recognize the risk factors of DN and track its evolution and progression, that 
will ameliorate the efficacy of treatment. This study is aimed to compare renal function with subclinical hypothyroidism. The study objectives are to

1.To estimate serum TSH, serum FT4, serum creatinine and eGFR in type 2 diabetes mellitus (T2DM) with and without subclinical hypothyroidism.

2.To compare serum TSH, serum FT4, serum creatinine, eGFR and HbAlc between the above said two groups.

\section{MATERIAL AND METHODS}

This study aimed to compare renal function in persons with T2DM with subclinical hypothyroidism (group A) and without subclinical hypothyroidism (group B). It included 215 adults, who attended OPD General Medicine, GSL General hospital, Rajahmundry, A.P., out of which 29 subjects were found to have subclinical hypothyroidism and 186 subjects were found to be without subclinical hypothyroidism. Thyroid function test is done by immunoassay and TSH value of $5-10 \mathrm{mIU} / 1$ with normal free T4 is considered as having subclinical hypothyroidism. In all subject's kidney profile including serum creatinine and eGFR using MDRD formula was done. Anthropometric and hemodynamic details were obtained of all study subjects. Blood samples were used for estimation of $\mathrm{HbA} 1 \mathrm{c}$ and serum creatinine. After 12 hours overnight fasting, samples were collected for TSH and FT4 estimations by standard immunoenzymatic procedures.

\section{Inclusion criteria:}

- Cases of known T2DM aged between $30-70$ years.

\section{Exclusion criteria:}

- Cases of T1DM.

- Cases of non diabetic kidney diseases.

- Cases on nephrotoxic drugs.

- Cases with history of thyroid disorder or anti thyroid medications.

- Cases of diabetes mellitus with pregnancy.

- Cases of gestational diabetes mellitus.

- Cases with autoimmune diseases.

- Cases with acute chronic illness.

\section{List of investigations done:}
1. HbAlc
2. Serum TSH
3. Serum FT4
4. Serum creatinine

Renal function was screened by performing serum creatinine by alkaline picrate method and confirmation was done by eGFR using ID - MS traceable MDRD formula. Thyroid function was assessed by immunoassay using ELFA method. Informed consent was obtained from all study subjects, and the ethics committee of tertiary care hospital approved the study. Statistical analysis: was done using an online statistical software system, Graph Pad Prism and Microsoft excel 2007. Online Pearson's correlation was applied to assess the association between thyroid hormones and DN. Data were expressed as mean \pm SD. Statistical analysis included the unpaired t-test (for continuous measures). All known potential confounders (age, sex, HbAlc, serum TSH, serum FT4, serum creatinine) were entered in univariable model to ensure giving an unbiased estimate for the relation between subclinical hypothyroidism with DN and without DN. A p-value of $<$ 0.05 was considered to be statistically significant.

\section{RESULTS}

Table 1 shows the age distribution of males and females. The minimum age in the male group was 32 years and the maximum age was 70 years, mean \pm SD was $53.90 \pm$ 10.06. Minimum age in the female group was 30 years and maximum age was 70 years, mean $\pm \mathrm{SD}$ was $54.10 \pm$ 10.99. Table 2 shows groups distribution among males and females. The number of males with T2DM with subclinical hypothyroidism were 9 and without subclinical hypothyroidism were 63 . The number of females with T2DM with subclinical hypothyroidism were 20 and without subclinical hypothyroidism were 123. The percentage of type 2 diabetic males with subclinical hypothyroidism was $12.5 \%$ and without subclinical hypothyroidism was $87.5 \%$. Among the female group, type 2 diabetic females with subclinical hypothyroidism was $13.98 \%$ and without subclinical hypothyroidism was $86.01 \%$. Table 4 shows the biochemical parameters in diabetics with subclinical hypothyroidism (group $\mathrm{A}, \mathrm{n}=29$ ) and diabetics without subclinical hypothyroidism group $\mathrm{B}, \mathrm{n}=186$ ). The mean Serum TSH, Serum creatinine in group A was significantly higher than in group B $(p<0.0001, p=$ 0.004 respectively). The mean HbA1c and Serum FT4 however did not show any significance among the two groups. The mean eGFR in group A showed significantly lower levels when compared to Group B $(\mathrm{p}=0.019)$.

\begin{tabular}{ccc}
\multicolumn{4}{c}{ Table 1: showing age distribution of males and females } \\
\hline Age (years) & Males $(\mathbf{n}=\mathbf{7 2})$ & Females $(\mathbf{n}=143)$ \\
\hline Minimum & 32 & 30 \\
Maximum & 70 & 70 \\
Mean \pm SD & $53.90 \pm 10.06$ & $54.10 \pm 10.99$ \\
\hline
\end{tabular}


Table 2: showing groups distribution among males and females

\begin{tabular}{ccccc}
\hline Groups & \multicolumn{2}{c}{ Males $(\mathrm{n}=72)$} & \multicolumn{2}{c}{ Females $(\mathrm{n}=143)$} \\
\hline & No: & $\%$ & No: & $\%$ \\
T2DM with SCH (group A) & 9 & 12.5 & 20 & 13.98 \\
T2DM without SCH (group B) & 63 & 87.5 & 123 & 86.01 \\
\hline
\end{tabular}

Table 3: Showing the biochemical parameters in diabetics with and without subclinical hypothyroidism (SCH)

\begin{tabular}{cccc}
\hline Parameters & T2DM with SCH & T2DM without SCH & p-value \\
\hline Age (years) & & & \\
Range & $39-70$ & $30-70$ & \\
Mean \pm SD & $56.48 \pm 9.97$ & $53.65 \pm 10.73$ & $=0.18$ \\
HbA1c (\%) & & & \\
Range & $6.52-7.99$ & $6.48-7.91$ & $=0.74$ \\
Mean \pm SD & $6.96 \pm 0.41$ & $6.99 \pm 0.42$ & \\
Serum TSH (mU/l) & & & \\
Range & $4.15-10.1$ & $0.42-4.66$ & \\
Mean \pm SD & $7.51 \pm 1.99$ & $2.66 \pm 1.10$ & $<0.0001^{*}$ \\
Serum FT4 (ng/dl) & & & \\
Range & $0.83-2.8$ & $0.81-2.81$ & \\
Mean \pm SD & $1.72 \pm 0.50$ & $1.71 \pm 0.51$ & $=0.969$ \\
Serum creatinine (mg/dl) & & & \\
Range & $0.99-1.49$ & $0.87-1.38$ & \\
Mean \pm SD & $1.22 \pm 0.12$ & $1.14 \pm 0.14$ & $=0.004^{*}$ \\
eGFR (ml/min/1.73 $\mathrm{m}^{2}$ ) & & & \\
Range & $40.66-79.43$ & $40.29-99.16$ & \\
Mean \pm SD & $54.14 \pm 9.85$ & $61.16 \pm 15.52$ & $=0.019^{*}$ \\
\hline
\end{tabular}

\section{DISCUSSION}

In this study, we determined the comparison of renal function in persons with T2DM with and without $\mathrm{SCH}$. Our results confer that type 2 diabetic subjects with $\mathrm{SCH}$ are proned to develop DN when compared with type 2 diabetic subjects without $\mathrm{SCH}$. After lining up for likely risk factors of DN (age, sex, HbAlc levels, serum creatinine and eGFR) low to normal FT4 levels and high to normal TSH levels were significantly associated with decreased renal function. These findings suggest that low to normal thyroid hormone levels can be a likely risk factor for development of DN. Clinical studies have systematically showed that both poor control of glycemic status and hypertension are associated with DN. Another study reported that glycemic control $(\mathrm{HbAlc}$ level $<7 \%$ ) was related with decreased microvascular injury. In our study we found that persons with poor control of glycemic status with $\mathrm{SCH}$ progressed to develop DN when compared to those without SCH. Other studies, in addition to traditional risk factors of $\mathrm{DN}$, showed that thyroid function is related closely to the development of DN. Several studies ${ }^{20}$, suggested increased prevalence of DN in diabetic patients who suffered from $\mathrm{SCH}$ or hypothyroidism. Further, replacement therapy with LT4 might decrease the risk of DN, like reducing uric acid levels, blood lipid, improving renal blood flow by raising GFR and slowing down the progression of kidney damage in such patients Clinical trials, showed that thyroid hormones are extremely related with secretion of insulin in euthyroid individuals. Other studies reported that increased insulin levels are related to decreased prevalence of $\mathrm{DN}$ in $\mathrm{T} 2 \mathrm{DM}$ patients. Low thyroid hormone levels can directly result in DN by worsening vascular function ${ }^{3}$. Serum levels of FT3 have been shown related to endothelial dysfunction in patients with chronic kidney disease as determined by flow-mediated dilation. Patients with hypothyroidism and also those with $\mathrm{SCH}$, go through endothelial dysfunction as a result of reduced availability of nitric oxide, that can be reversed by supplementation of $\mathrm{LT}_{4}$. Endothelial dysfunction is considered to have an effect on initiation of $\mathrm{DN}$, its progression and clinical sequelae. Other previous studies reported low thyroid hormone levels may occur in patients with serious illnesses. In patients with chronic kidney disease, low levels of FT3 have been regarded as independent predictor of mortality. With regard to the above data, it is suggested that low to normal thyroid hormone levels can be considered as a biomarker for DN and indicate accompanying prognosis of the patient. A study on patients with T2DM with euthyroid status demonstrated significant relation between high TSH levels and low to normal levels of thyroid hormones with magnified frequency of development of $\mathrm{DN}^{3}$ but our study showed high TSH levels and normal FT4 levels with increased incidence of decreased renal function in persons with T2DM. Study in Taiwan reported, in 588 
T2DM subjects $\mathrm{SCH}$ was related to increased prevalence of DN and not diabetic retinopathy bur our study showed 215 T2DM subjects with 29 persons suffering from $\mathrm{SCH}$ were associated with increased progression of $\mathrm{DN}$ alone. The raised incidence of chronic kidney disease emphasize the need for further understanding the impact of thyroid hormone therapy. Studies in $\mathrm{db} / \mathrm{db}$ mice suggested that $\mathrm{T} 3$ may prevent progressive damage to the kidney and remodelling by meliorating insulin signalling. Further research is recommended to dig into the involving association between $\mathrm{SCH}, \mathrm{DN}$ and related complications.

\section{CONCLUSION}

The development of DN in type 2 diabetic persons with $\mathrm{SCH}$ is relatively common when compared with those without $\mathrm{SCH}$ and with those with normal thyroid function. Hence it is necessary to screen for thyroid function in persons with T2DM that may have an effect on renal function. Further research can dig into the causative association between $\mathrm{SCH}, \mathrm{DN}$ and its complications by prospective and interventional studies.

\section{REFERENCES}

1. Xu Y, Wang L, He J, Bi Y, Li M, Wang T, Wang L, Jiang Y, Dai M, Lu J, Xu M, Li Y, Hu N, et al, and 2010 China Noncommunicable Disease Surveillance Group. Prevalence and control of diabetes in Chinese adults. JAMA. 2013; 310:948-59. https://doi.org/10.1001/jama.2013.168118.

2. Menke A, Casagrande S, Geiss L, Cowie CC. Prevalence of and Trends in Diabetes Among Adults in the UnitedStates, 1988-2012. JAMA. 2015; 314:1021-9. https://doi. org/10.1001/jama.2015.10029.

3. Jian Wang1,*, Huiqin Li, Mingjuan Tan, Gu Gao1, Ying Zhang1, Bo Ding1, Xiaofei Su1, Xiaocen Kong1 and Jianhua Ma1Association between thyroid function and diabetic nephropathy in euthyroid subjects with type 2 diabetes mellitus: a crosssectional study in China. 2019, Vol. 10, (No. 2), pp: 88-97.

4. Tuttle KR, Bakris GL, Bilous RW, Chiang JL, de Boer IH, Goldstein-Fuchs J, Hirsch IB, Kalantar-Zadeh K, Narva AS, Navaneethan SD, Neumiller JJ, Patel UD, Ratner RE, et al. Diabetic kidney disease: a report from an $\mathrm{ADA}$ Consensus Conference. Diabetes Care. 2014; 37:2864-83. https://doi. org/10.2337/dc14-1296.

5. Iglesias P, Bajo MA, Selgas R, Diez JJ. Thyroid dysfunction and kidney disease: An update. Rev Endocr Metab Disord. 2017; 18:131-44. https://doi.org/10.1007/ s11154-016-9395-7.

6. Iglesias P, Diez JJ. Thyroid dysfunction and kidney disease. Eur J Endocrinol. 2009; 160:503-15. https://doi. org/10.1530/EJE-08-0837.

7. Gopinath B, Harris DC, Wall JR, Kifley A, Mitchell P. Relationship between thyroid dysfunction and chronic kidney disease in community-dwelling older adults. Maturitas. 2013; 75:159-64. https://doi.org/10.1016/j. maturitas.2013.03.009.

8. Woodward A, McCann S, Al-Jubouri M. The relationship between estimated glomerular filtration rate and thyroid function: an observational study. Ann Clin Biochem. 2008; 45:515-7. https://doi.org/10.1258/acb.2008.007248.

9. Jia F, Tian J, Deng F, Yang G, Long M, Cheng W, Wang B, Wu J, Liu D. Subclinical hypothyroidism and the associations with macrovascular complications and chronic kidney disease in patients with Type 2 diabetes. Diabet Med. 2015; 32:1097-103. https://doi.org/10.1111/dme.12724.

10. El-Eshmawy MM, Abd El-Hafez HA, El Shabrawy WO, Abdel Aal IA. Response: subclinical hypothyroidism is independently associated with microalbuminuria in a cohort of prediabetic egyptian adults (diabetes metab j 2013;37:450-7). Diabetes Metab J. 2014; 38:85-6. https:// doi.org/10.4093/dmj.2014.38.1.85.

11. Asvold BO, Bjoro T, Vatten LJ. Associations of TSH levels within the reference range with future blood pressure and lipid concentrations: 11-year follow-up of the HUNT study. Eur J Endocrinol. 2013; 169:73-82. https://doi.org/10.1530/ EJE-13-0087.

12. Wang J, Zheng X, Sun M, Wang Z, Fu Q, Shi Y, Cao M, Zhu Z, Meng C, Mao J, Yang F, Huang X, Xu J, et al. Low serum free thyroxine concentrations associate with increased arterial stiffness in euthyroid subjects: a population-based cross-sectional study. Endocrine. 2015; 50:465-73. https://doi.org/10.1007/s12020-015-0602-1.

13. Asvold BO, Bjoro T, Nilsen TI, Gunnell D, Vatten LJ. Thyrotropin levels and risk of fatal coronary heart disease: the HUNT study. Arch Intern Med. 2008; 168:855-60. https://doi.org/10.1001/archinte.168.8.855.

14. Asvold BO, Bjoro T, Platou C, Vatten LJ. Thyroid function and the risk of coronary heart disease: 12-year follow-up of the HUNT study in Norway. Clin Endocrinol (Oxf). 2012; 77:911-7. https:/doi. org/10.1111/j.13652265.2012.04477.x

15. Levey A S, Coresh J, et al. expressing the MDRD study equation for estimating GFR with IDMS traceable (gold standard) serum creatinine values. J Am Soc Nephrol 2005;16:69A.

16. Zimmet P, Alberti KG, Shaw J. Global and societal implications of the diabetes epidemic. Nature 2001;414:782-7.

17. Fineberg D, Jandeleit-Dahm KA, Cooper ME. Diabetic nephropathy: diagnosis and treatment. Nat Rev Endocrinol. 2013; 9:713-23. https://doi.org/10.1038/nrendo.2013.184.

18. The Diabetes Control and Complications (DCCT) Research Group. Effect of intensive therapy on the development and progression of diabetic nephropathy in the Diabetes Control and Complications Trial. Kidney Int. 1995; 47:1703-20. https://doi.org/10.1038/ki.1995.236.

19. Furukawa S, Yamamoto S, Todo Y, Maruyama K, Miyake T, Ueda T, Niiya T, Senba T, Torisu M, Kumagi T, Miyauchi S, Sakai T, Minami H, et al. Association between subclinical hypothyroidism and diabetic nephropathy in patients with type 2 diabetes mellitus. Endocr J. 2014; 61:1011-8.

20. Chen HS, Wu TE, Jap TS, Lu RA, Wang ML, Chen RL, Lin HD. Subclinical hypothyroidism is a risk factor for nephropathy and cardiovascular diseases in Type 2 diabetic patients. Diabet Med. 2007; 24:1336-44. https://doi. org/10.1111/j.1464-5491.2007.02270.x.

21. Liu P, Liu R, Chen X, Chen Y, Wang D, Zhang F, Wang Y. Can levothyroxine treatment reduce urinary albumin 
excretion rate in patients with early type 2 diabetic nephropathy and subclinical hypothyroidism? A randomized double-blind and placebo-controlled study. Curr Med Res Opin. 2015; 31:2233-40. https://doi.org/10.1185/03007995 .2015.1094044.

22. Shin DH, Lee MJ, Lee HS, Oh HJ, Ko KI, Kim CH, Doh FM, Koo HM, Kim HR, Han JH, Park JT, Han SH, Yoo $\mathrm{TH}$, et al. Thyroid hormone replacement therapy attenuates the decline of renal function in chronic kidney disease patients with subclinical hypothyroidism. Thyroid. 2013; 23:654-61. https://doi.org/10.1089/thy.2012.0475.

23. Ortega E, Koska J, Pannacciulli N, Bunt JC, Krakoff J. Free triiodothyronine plasma concentrations are positively associated with insulin secretion in euthyroid individuals. Eur J Endocrinol. 2008; 158:217-21. https:// doi.org/10.1530/EJE-07-0592.

24. Fernandez-Real JM, Lopez-Bermejo A, Castro A, Casamitjana R, Ricart W. Thyroid function is intrinsically linked to insulin sensitivity and endothelium-dependent vasodilation in healthy euthyroid subjects. J Clin Endocrinol Metab. 2006; 91:3337-43. https://doi.org/10.1210/ jc.2006-0841.

25. Bo S, Gentile L, Castiglione A, Prandi V, Canil S, Ghigo E, Ciccone G. C-peptide and the risk for incident complications and mortality in type 2 diabetic patients: a retrospective cohort study after a 14-year follow-up. Eur J Endocrinol. 2012; 167:173-80. https://doi.org/10.1530/ EJE-12-0085.

26. Yilmaz MI, Sonmez A, Karaman M, Ay SA, Saglam M, Yaman H, Kilic S, Eyileten T, Caglar K, Oguz Y, Vural A, Yenicesu M, Zoccali C. Low triiodothyronine alters flow- mediated vasodilatation in advanced nondiabetic kidney disease. Am J Nephrol. 2011; 33:25-32. https://doi. org/10.1159/000322581.

27. Taddei S, Caraccio N, Virdis A, Dardano A, Versari D, Ghiadoni L, Salvetti A, Ferrannini E, Monzani F. Impaired endothelium-dependent vasodilatation in subclinical hypothyroidism: beneficial effect of levothyroxine therapy. J Clin Endocrinol Metab. 2003; 88:3731-7. https://doi. org/10.1210/jc.2003-030039.

28. Schalkwijk CG, Stehouwer CD. Vascular complications in diabetes mellitus: the role of endothelial dysfunction. Clin Sci (Lond). 2005; 109:143-59. https://doi.org/10.1042/ CS20050025.

29. Wu GH, Kong FZ, Cheng QZ, Luo WF, Du XD. Low T3 syndrome predicts severe neurological deficits of cerebral infarction inpatients with large artery artherosclerosis in internal carotid artery system. Neuro Endocrinol Lett. 2014; 35:149-53.

30. Ozcan KS, Osmonov D, Toprak E, Gungor B, Tatlisu A, Ekmekci A, Kaya A, Tayyareci G, Erdinler I. Sick euthyroid syndrome is associated with poor prognosis in patients with ST segment elevation myocardial infarction undergoing primary percutaneous intervention. Cardiol J. 2014; 21:238- 44. https://doi.org/10.5603/CJ.a2013.0108.

31. Zoccali C, Mallamaci F, Tripepi G, Cutrupi S, Pizzini P. Low triiodothyronine and survival in end-stage renal disease. Kidney Int. 2006; 70:523-8. https://doi. org/10.1038/sj.ki.5001566.

32. Diez JJ, Sanchez P, Iglesias P.- prevalence of thyroid dysfunction in patients with type 2 diabetes - Exp Clin Endocrinol Diabetes.2011 Apr;119(4):201-7.

Source of Support: None Declared Conflict of Interest: None Declared 